\title{
VIOLENT ERASURES: ATROCITY, PHOTOGRAPHIC ARCHIVES AND THE ALGERIAN WAR OF INDEPENDENCE (I954-62)
}

\author{
Katarzyna Falęcka
}

The cover of the French bimonthly magazine Manière de voir-Le Monde diplomatique, published in February-March 2012 on the of Independence (I954-I962), featured a photograph showing two men overlooking the sea (2012, figure I). Sitting carelessly on the edge of the shore, their backs turned to the camera, they seem unaware of having become subjects of a photograph. The blur, tilt and hasty framing of the scene suggest that the photographer remained in motion while pressing the shutter button, producing a snapshot devoid of the sharpness and glossiness of press photography. The photograph offers no information regarding the identities of the men, turning the magazine's readers into viewers who can only catch a glimpse of the scene. The resulting instability of both vision and representation stands in sharp contrast to the way the issue presents itself: entitled Algérie, 1954-2012. Histoire et espérances [Algeria, 1954-2012. History and Hopes], it acts as a frame, quite literally 'a way of seeing', through which to examine over half a century of Algerian history.

As readers flip through the pages of the magazine, which collects articles previously published in Le Monde diplomatique, their ability to 'see' remains under pressure: on page after page, the photographs reveal only fragments of scenes and obfuscate photographic information behind the filter of blurred representation. The 60 or so predominantly colour photographs are attributed to photographer Bruno Boudjelal and span almost 20 years of his practice, beginning with his first journey to Algeria in I993. The magazine is divided into three sections, which address: the hopes associated with Algerian independence in I962; the disillusionment that followed the rise of an increasingly authoritarian government and the outbreak of a civil war in I99I; and, finally, the memorial legacy of the Algerian War 

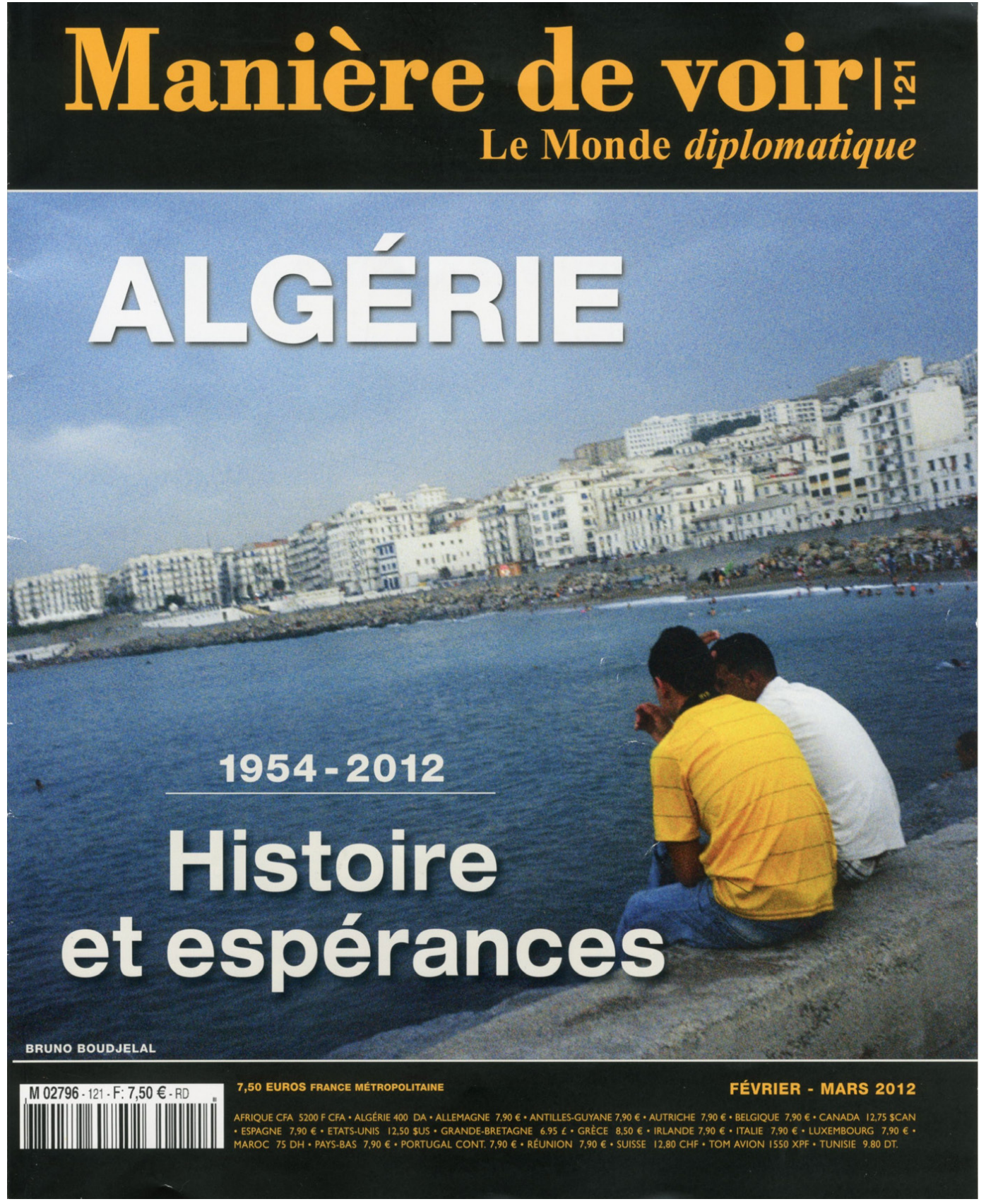

Figure I 'Algérie, I954-20I2. Histoire et espérances', Manière de voir-Le Monde diplomatique, no. I2I, February-March 2012. Cover page with photograph by Bruno Boudjelal. (C) Bruno Boudjelal and Agence VU. 
of Independence. ${ }^{\mathrm{I}}$ There is a temporal dissonance between the historical focus of the journalistic texts and Boudjelal's photographs, which were taken in the last two decades of the nearly 60-year-long period discussed in the magazine. In fact, Boudjelal's pictorial narrative is only punctuated by a single archival photograph, produced during the Algerian War of Independence, and printed in the final section, entitled 'Le Poids de la mémoire' ['The Weight of Memory'].

While the shortage of historical photographs reproduced in the issue could be read as reflective of a lack of images of the conflict altogether, the partial opening of the first French army archives in 1992 revealed that competing groups actively employed photographic practices in the development of various strategies of communication and legitimation of their warfare. ${ }^{2}$ However, the production and circulation of these images during the war was governed by strict control and rules that determined what could and what could not be shown. ${ }^{3}$ Once the conflict had ended, restrictions were also imposed on archival material following its transportation from Algeria to France after the Évian Accords in $1962 .{ }^{4}$ Most documents produced by the French army were subject to a 50-year-long delay, becoming only slowly available at the time of Manière de voir's publication. Some of the 'sensitive' archival documents, however, remain subject to a 75 - or Ioo-year delay. ${ }^{5}$

Writing in I99I, a year before the first archives were made accessible, Benjamin Stora suggested that the scarcity of visual representations of the war - both those produced during the conflict and those produced in its aftermath - had fuelled historical amnesia in France. ${ }^{6}$ There was a 'noncompromise', Stora argued, between the written testimonies from the war and the visual representations that could support them, but which remained absent. ${ }^{7}$ The war's memorial legacy relied thus on written testimonies and accounts rather than on images. ${ }^{8}$ In 2012, when the issue of Manière de voir was published, the atmosphere in France had changed from that of I99 I when Stora argued, in La gangrène et l'oubli: La mémoire de la guerre d'Algérie [Gangrene and Forgetting: The Memory of the Algerian War], for the war's invisibility in the French collective imagination. The large number of publications devoted to the conflict in 2012 declared the end of amnesia. ${ }^{9}$ Nevertheless, Stora noted that the work of historians and intellectuals should not be conflated with an official state recognition of the conflict, cautioning against assumptions that a clarity of vision regarding the war had been reached in France. ${ }^{\text {Io }}$ In light 
of these shifts, why did Manière de voir feature only one archival photograph, risking once again relegating the conflict to the realm of invisibility?

The paradoxical editorial decision to refuse to deploy the increasingly available photographic archives and instead address the war through a contemporary photographic project compels us to reassess the war's (in) visibility and the role of images in producing, reproducing and challenging collective visions of the past. In this article, I want to consider Manière de voir in relation to the long-held conviction that the war was underrepresented, and what Stora assumed was its attendant absence from the French collective imagination. By analysing its iconographical programme, I will argue that Manière de voir identifies that which does not readily find its representation in photographic archives, yet without relegating these events to the field of invisibility. Rather, it mobilises Boudjelal's photographs to critically address the blind spots embedded in archival photography.

\section{Images cast out of history}

In the final pages of Manière de voir, a black-and-white portrait photograph of a young man arrests the reader's gaze (c. I954-62, figure 2). Looking confidently into the camera, the man holds his head high, yet the image tightly frames his face, leaving little space between its contours and the borders of the image. The grey card, which emerges from the bottom of the image with the number ' 80 ' written on it, has been cropped. Despite its fragmentation, the number suggests that the body represented in the photograph was identified, classified and controlled by a larger bureaucratic system. The face's frontal framing and numerical identification indicate that what we are looking at is a mugshot, a type of image whose roots are in the photographic portraiture of the mid-to-late nineteenth century. ${ }^{\text {II }}$

The caption underneath states that the man in the photograph, Hamid, was a 'fellagha' - a pejorative term used by the French army to describe a militant in the Algerian anti-colonial movement - who was captured, tortured and killed by the army during war. ${ }^{\mathrm{I} 2}$ Neither the photograph nor the caption reveal the circumstances of his capture, nor the place and time of his death. Marked by the passage of time, the photograph has faded and the card has begun to blend with the man's skin.

Prior to being reproduced in the magazine, the mugshot had appeared in Bruno Boudjelal's Scrapbooks, published as part of the Disquiet Days/Jours 


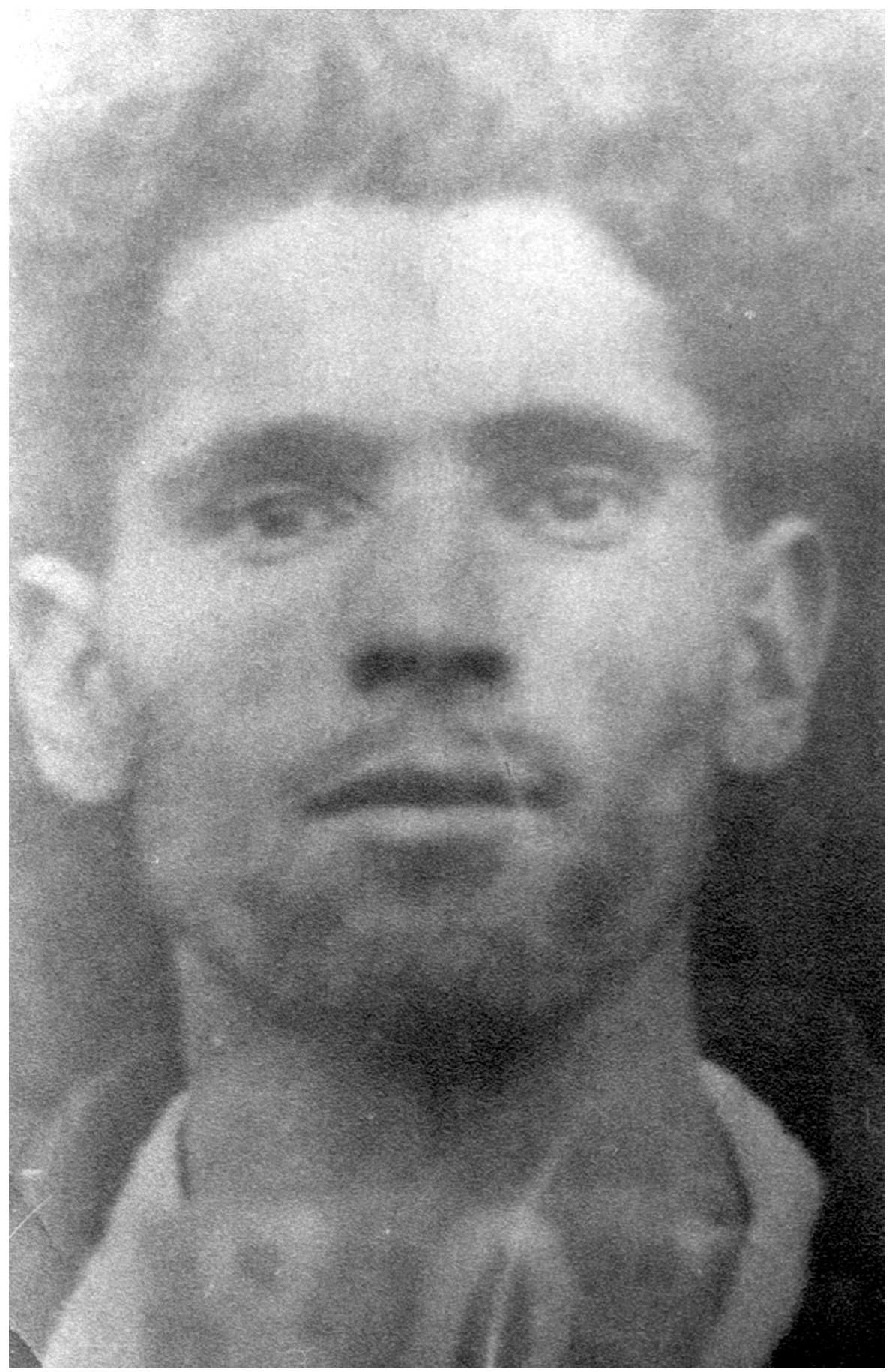

Figure 2 Hamid Boudjelal, c. I954-62. Black and white print / Hahnemühle Photo Rag Bright White 3 Io gr (copy of archival mugshot), $45 \mathrm{~cm} \times 30 \mathrm{~cm}$. Reprinted in Nicolas Bancel, Pascal Blachard and Sandrine Lemaire, 'La torture en miroir', Manière de voir-Le Monde diplomatique, no. I2 I, FebruaryMarch 20I2, pp. 80-83, p. 8I. (C) Bruno Boudjelal and Agence VU. 


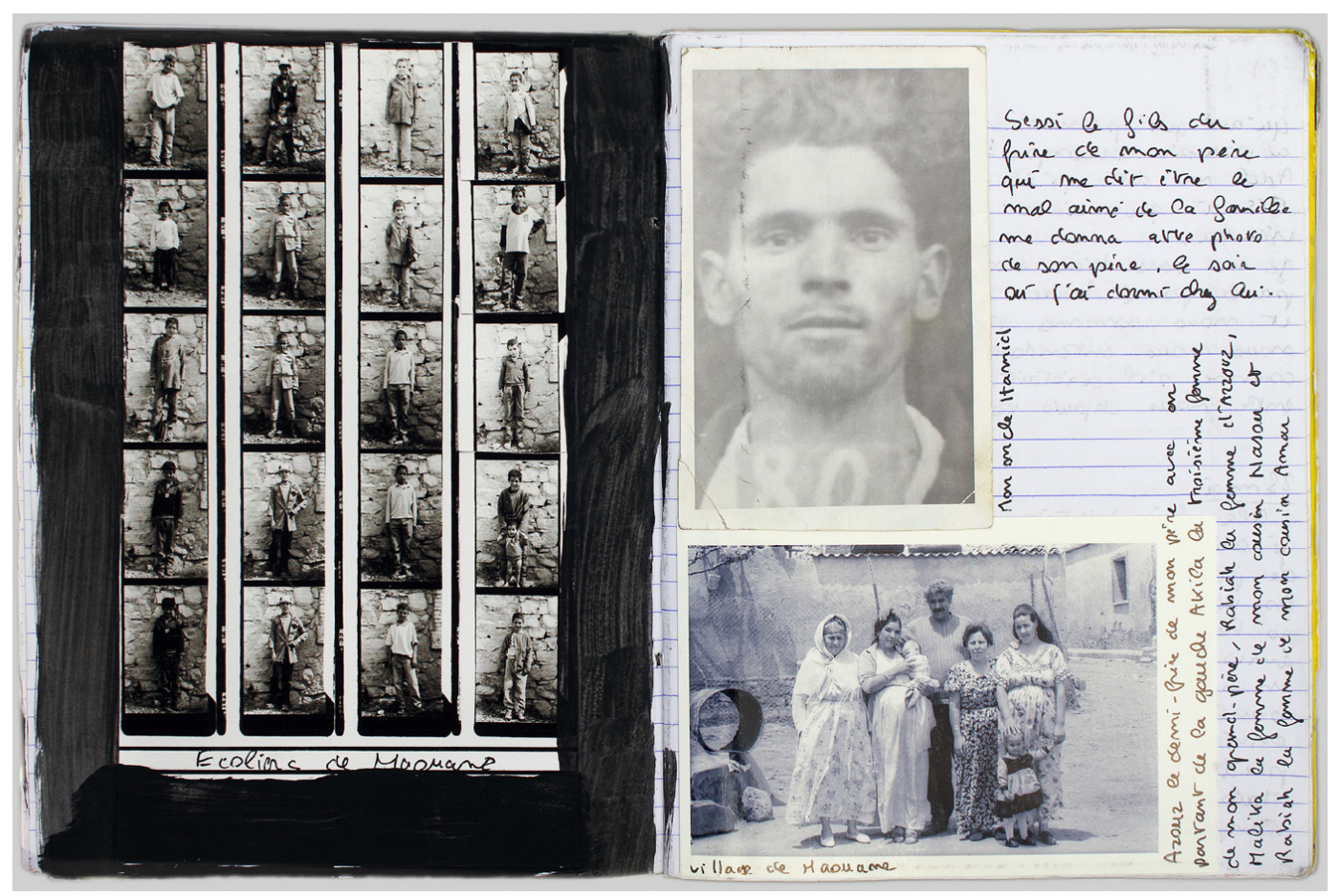

Figure 3 Bruno Boudjelal, Scrapbooks, 2009. Mixed media, $38 \mathrm{~cm} \times 24 \mathrm{~cm}$. C Bruno Boudjelal and Agence VU.

intranquilles photobook (2009, figure 3). ${ }^{13}$ Comprising Boudjelal's childhood photographs from France, his diary entries and photographs from trips to Algeria, found images of his Algerian family and the photographer's birth certificate, the series reflects an attempt to assemble a family album in the aftermath of a conflict that severed family ties. The son of an Algerian man who migrated to France at the outbreak of the war and claimed to be of Italian descent in order to facilitate his assimilation into French society at a time of extreme violence unfolding in the colony, Boudjelal grew up not really knowing where he came from. ${ }^{14}$ Due to his father's silence and his French maternal grandparents' avowed shame at their daughter's union with an Algerian man, Boudjelal's upbringing in France was marked by repression. His family history illustrates in microcosm the complexity of Algerian-French relations, as it embodies, and grows out of, the historical proximity of the two countries as well as their abrupt, even brutal separation. Hamid, the caption underneath the mugshot in Manière de voir explains, was the photographer's paternal uncle. 
As we learn from Boudjelal's notes in Scrapbooks, Hamid was arrested by the French police under suspicion of having supplied food to resistants' camps. ${ }^{\text {Is }}$ The photograph included in the series is a copy of the original image produced by the French police following Hamid's capture. ${ }^{\text {I6 }}$ In Manière de voir, the mugshot is inset in an article querying the French official version of history surrounding the use of torture in Algeria, suggesting that '[c]ar la France n'a pas su rassembler tous les fragments du miroir, ce qui permettrait de comprendre qu'il faisait système, qu'il constituait une part importante de son imaginaire collectif [France did not know how to reassemble all of the fragments of the mirror, an act that would have enabled it to understand the system it was part of and which constituted an important part of its collective imaginary]. ${ }^{17}$ Nevertheless, the mugshot does not visualise torture itself, it only sheds light on the moments preceding the violence that was to come.

In her discussion of the Western media's portrayal of armed conflict and its casualties, Judith Butler has argued that war imagery is determined by a 'field of representability' constituted by a set of rules that define what can be shown and what remains outside of the photographic image. ${ }^{18}$ This field is conditioned by regulations which prohibit 'a set of contents and perspectives' from appearing and is delineated by a 'frame' which operates silently to control representation. ${ }^{19}$ As Stora has demonstrated, strict military censorship during the war in Algeria resulted in selective visualisations of violence; for example, atrocities enacted by opposing Algerian forces were well-documented while the suffering caused by the French army unfolded far away from photographic cameras. ${ }^{20}$ Thus, the army actively produced what Butler has defined as the 'frame' of war imagery.

Torture too became an underrepresented element of war. The small number of representations of this act resonates with an understanding of torture as an opaquely 'private' moment, which is kept away from the public. Henri Alleg, a French communist who fought for the liberation of Algeria and who was tortured by the French army, described in his memoir La Question [The Question] (I958) the torture he underwent in an unfinished building, a nondescript site, uninhabited and austere, situated on the outskirts of Algiers. ${ }^{21}$ In war-torn Algeria, torture was never officially sanctioned by French officials although it was unofficially encouraged. ${ }^{22}$ Both present and absent, torture was continuously silenced by the French state during and after the war, even though various individuals and groups - including 
Alleg - resisted these occlusions. As late as 2000, the publication of Louisette Ighilahriz's testimony in the pages of Le Monde resulted in controversy. ${ }^{23}$ Despite the passage of almost 40 years since the end of the war, her account of the rape and torture that she endured as a young resistance fighter in the hands of key French military officials caused uproar among French veterans. ${ }^{24}$ However, the story she recounted triggered a confession from General Jacques Massu some months later, who admitted that the use of torture formed part of the 'general atmosphere' of the war. ${ }^{25}$ The subject entered more forcefully into national debate by November 2000, causing President Jacques Chirac and the Prime Minister Lionel Jospin to admit, under growing pressure from the public, that torture was used during the war. ${ }^{26}$ However, they stopped short of condemning it.

The history of torture was thus transmitted through written and oral testimonies rather than photographic records; this became the field in which Stora's 'non-compromise' between image and text was evidently played out. Hidden from the eyes of the public and from cameras owing to the use of obscure spaces, torture remained one of the most contested aspects of the war in the decades that followed the end of the conflict. The shortage of visual evidence or representations further challenged the ability of victims to present testimonies that would stand firmly against those given by former soldiers and officers. ${ }^{27}$ This visual impasse contrasts strongly with Alleg's description of torture as a spectacle of excessive violence, one that would be eagerly witnessed by soldiers in moments of collective voyeurism. ${ }^{28}$ In 2000, in an attempt to correct the imbalance, the Musée National du Moudjahid in Algiers released a photograph, subsequently featured in Le Monde 2, which depicted a scene of torture that was later found to have been fabricated. ${ }^{29}$

However, it must be noted that representations of torture from the war do, in fact, exist. ${ }^{30}$ In May 2012, three months after the publication of Manière de voir, three grainy black-and-white photographs taken by Jean-Philippe Charbonnier, which show Algerian suspects being tortured in Kabylie, were included in the exhibition 'Algérie I830-I962, avec Jacques Ferrandez' at the Army Museum in Paris. ${ }^{3 \mathrm{I}}$ These were produced by Charbonnier during a trip to Algeria in 1957, when he was commissioned to work on a report titled 'Le Journal de bord d'un haut fonctionnaire en Algérie' ['Diary of a Senior Official in Algeria'] for the magazine Réalités, but were never printed in the final piece. ${ }^{32}$ They were later donated by the photographer to the 
Bibliothèque nationale de France on the condition that they would not be exhibited or reproduced. ${ }^{33}$ An exception was made for the exhibition and catalogue, in which two out of six existing images were reprinted, on the condition that the faces of the perpetrators were blurred. ${ }^{34}$ Anonymity was thus granted to the perpetrators rather than to the victims, and the original photographs became quickly buried in the archives following the exhibition's end. ${ }^{35}$ Notably, Laurent Gervereau and Stora's seminal book on the use of photography during the Algerian War of Independence, Photographier la guerre d'Algérie, published in 2004, does not discuss any representations of torture, merely stating that these do not exist. ${ }^{36}$

\section{The politics of blur}

In Manière de voir, the problematics of vision are addressed in an article by Anne Mathieu in which the author revisits Jean-Paul Sartre's writings on colonial violence in Algeria. ${ }^{37}$ Sartre had directed his attention to the events in Algeria in the first years of the war, when he supported the Front de libération nationale [National Liberation Front] (FLN), one of the Algerian nationalist and resistance movements. In his writing on the war, which included a preface to Alleg's memoir, Sartre, a witness to the blurred reality of the I950s and 6os, claimed that 'obsessed by her old dreams of glory and by the sense of her shame, France is struggling in the midst of a vague nightmare which she can neither flee nor decipher. Either we see clearly or we are done for' ${ }^{38}$

Sartre was writing in an attempt to mobilise French society to speak out against the conflict, to see through the propaganda machine and recognise the colonial violence that drove the warfare. Recycled half a century later, his words become relocated within Manière de voir onto the contested terrain of retrospective picturing rather than immediate witnessing. Not accidentally, the section in which Mathieu's article and Hamid's photograph appear is titled 'Le Poids de la mémoire' ['The Weight of Memory'], a clear nod to Les Lieux de mémoire [Realms of Memory] by Pierre Nora, written between I98 I and I992. In this multiple-volume project, Nora located moments in history which have become symbolic elements of the French memorial heritage and thus root French national identity. Notoriously, Nora failed to recognise the war in Algeria as a memorial marker, leading Perry Anderson to argue that the publication erased 'the entire imperial history of the country, from the Napoleonic conquests through the plunder of Algeria under the July 
Monarchy, to the seizure of Indochina in the Second Empire, and the vast African booty of the Third republic', turning these into a 'non-lieu' ['nonrealms'] of memory. ${ }^{39}$ Building on Anderson's critique, Michael Rothberg has discussed Nora's Les Lieux de mémoire as having 'an amnesiac relation to French colonial history and the impact of decolonization and postcolonial migrations'. ${ }^{40}$

Contrary to Sartre, and later Anderson, who advocated an end to blurred vision as a necessary condition for recognising the cruelty of the conflict and French colonial shame, Manière de voir opted for a visual narrative entirely immersed - with the exception of the mugshot - in fragmented, blurred and distorted representations of Algeria, as suggested by the cover image. For example, Boudjelal's early photographs of his family members living in the area of Sétif province in eastern Algeria emphasise the strangeness of what is meant to be seen as 'familiar'. An image of dancing women, reprinted in the magazine, dissolves their bodies into an assemblage of fluid, smoky forms (c. I997, figure 4). Failing against the women's fast movements, the camera

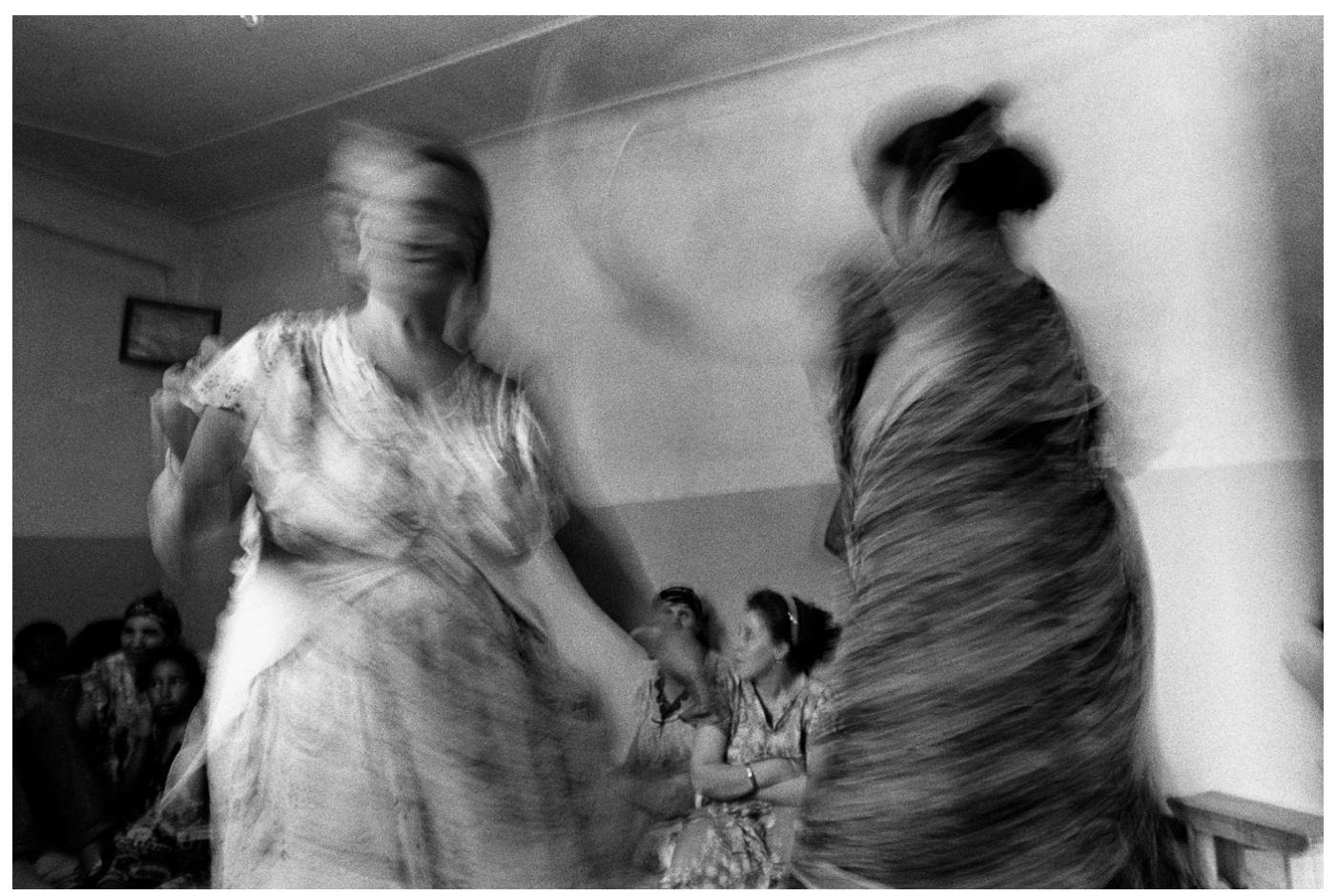

Figure 4 Bruno Boudjelal, Disquiet Days/Jours intranquilles, c. 1997. Black \& white print / Hahnemühle Photo Rag Bright White 3 Io gr, $30 \mathrm{~cm} \times 45 \mathrm{~cm}$. (C) Bruno Boudjelal and Agence VU. 


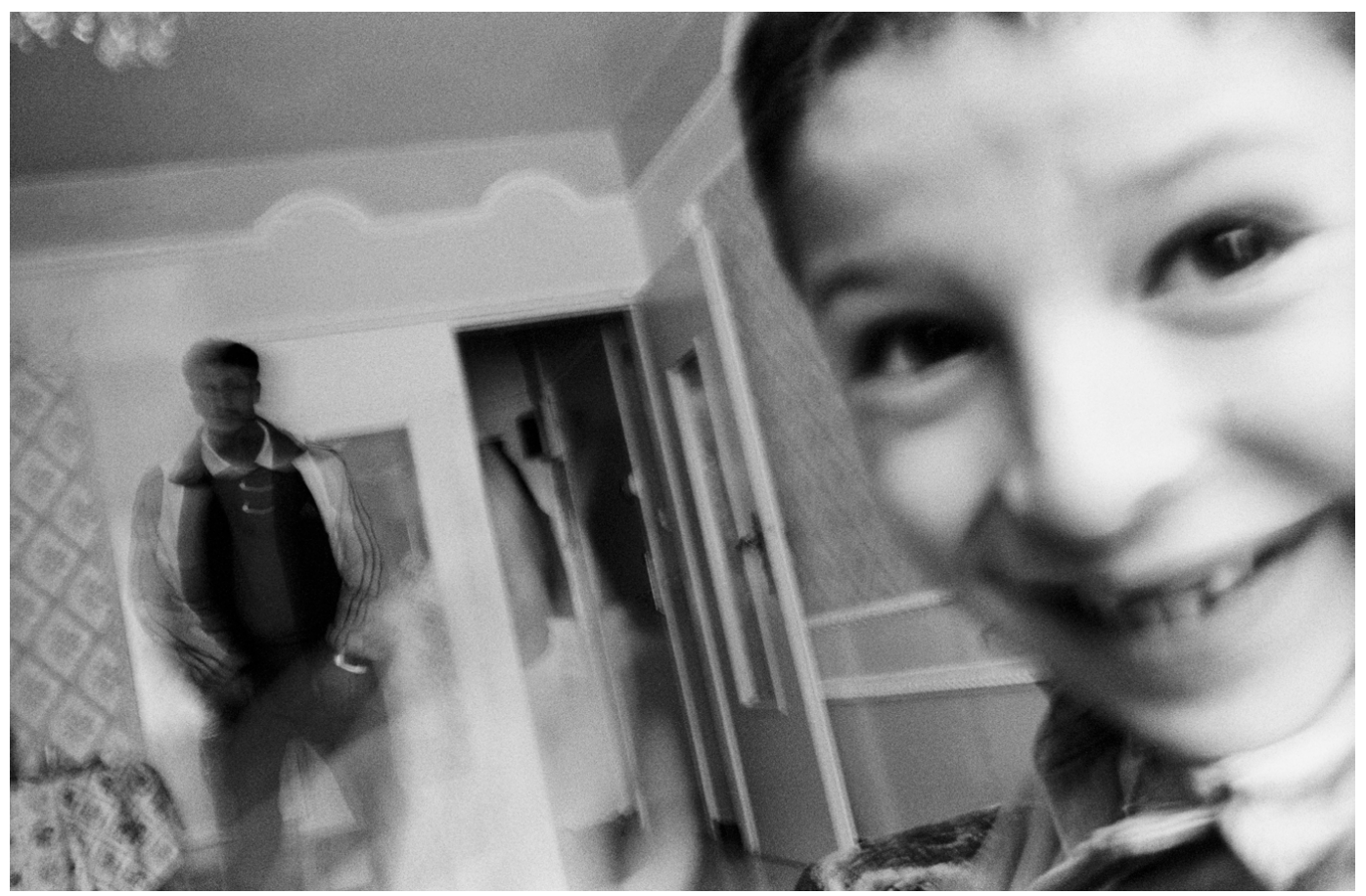

Figure 5 Bruno Boudjelal, Disquiet Days/Jours intranquilles, c. I993. Black \& white print / Hahnemühle Photo Rag Bright White 3 Io gr, $30 \mathrm{~cm} \times 45 \mathrm{~cm}$. C) Bruno Boudjelal and Agence VU.

has produced an image of abstract shapes figuring in the foreground, with the bodies extending beyond their own borders. In another photograph, included in Disquiet Days/Jours intranquilles, the smiling face of a young boy, which emerges from the lower right corner of the image, seems haunted by a male figure, subsumed in shadow, standing in the left corner of the picture (c. I993, figure 5). Other family members are shown reflected in mirrors or in close-ups which distort faces and reduce the identities of the sitters to textures inseparable from the grainy qualities of the photographic medium itself. Even Hamid's mugshot (once designed to provide irrefutable information) demarcates a space of alterity, governed as it is by a visual language devoid of intimacy, turning Scrapbooks into an eerie family album.

Boudjelal produced photographic blur through his own movements as well as the subjects', amplified by the use of simple lomography cameras with plastic lenses that offer few opportunities for focusing the image. While his photographic language is partly indicative of the social and political turmoil which governed Algeria at the time of his arrival - the civil war which 


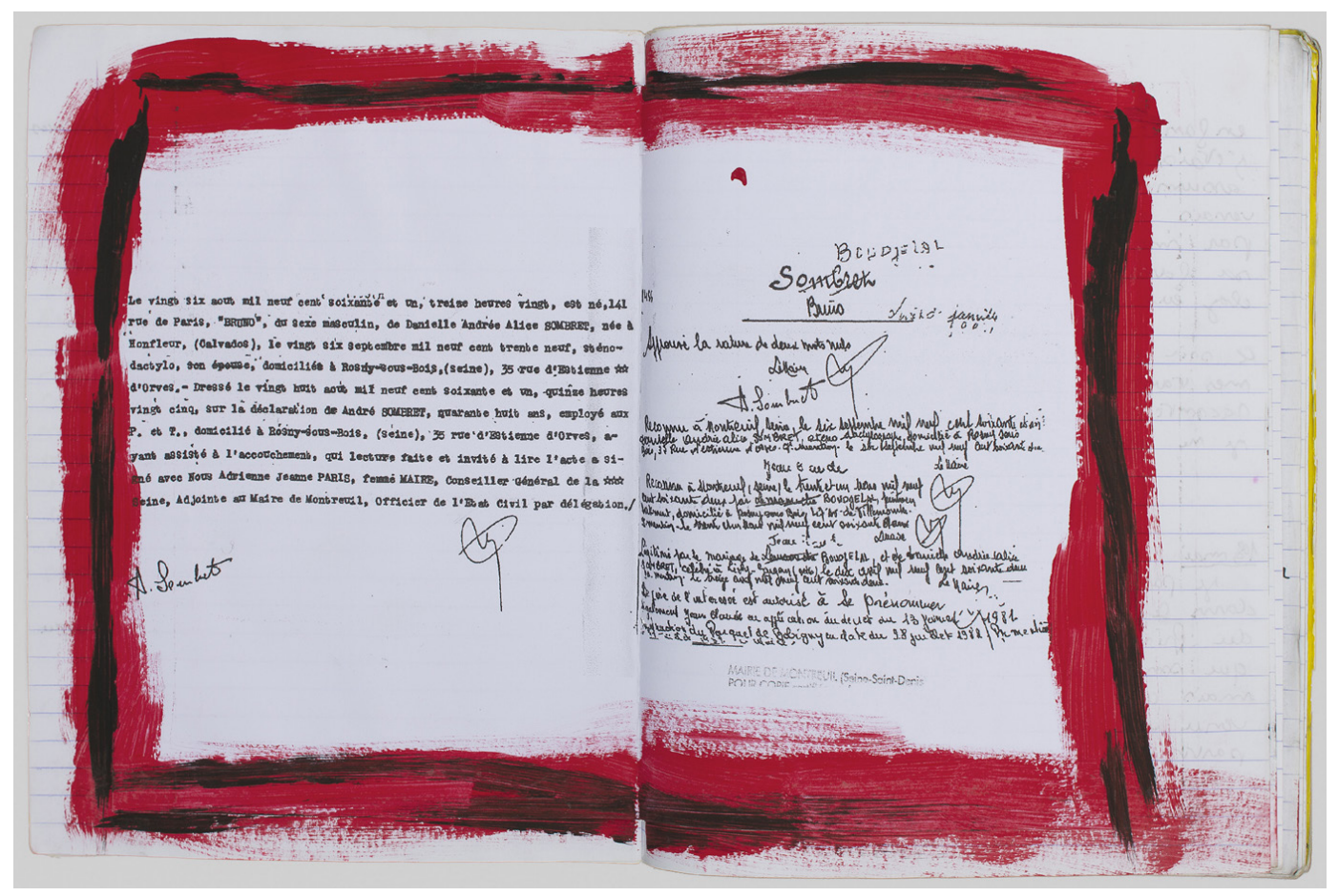

Figure 6 Bruno Boudjelal, Scrapbooks, 2009. Mixed media, $38 \mathrm{~cm} \times 24 \mathrm{~cm}$. (C) Bruno Boudjelal and Agence VU.

lasted from I99I to 2002, and during which the ability to photograph in public spaces was largely restricted - the focus on the private realm of the family as photographic subject in Boudjelal's early images suggests that he negotiated structures other than this immediate political context. ${ }^{4 \mathrm{I}}$ Scrapbooks foregrounds some of these concerns by opening with the photographer's birth certificate, on which the French maternal surname given to him at birth - 'Sombret' - has been crossed out and replaced by 'Boudjelal', his father's surname (2009, figure 6). These modifications to the original document continue as his father's given name, 'Lemaouche', is substituted with the French name 'Jean-Claude', which he adopted to conceal his Algerian heritage. These linguistic shifts reveal the entanglement of histories which Boudjelal's photographic project seeks to navigate.

Amanda Crawley has argued that Boudjelal's father embodies 'a sense of homelessness and enforced amnesia', one that visibly haunts the photographer in this project. ${ }^{42}$ Boudjelal further locates the roots of his own forgetting in his French family, claiming that 'from the moment I started living with them [his maternal grandparents], everything was done to conceal my origins from 
me, nothing could rise to the surface, everything had to be smoothed over. As though they wanted to turn me into an amnesiac'. ${ }^{43}$ It is not insignificant, therefore, that Boudjelal began his professional photography career in Algeria, where he had arrived in search of his 'origins', and that his conception of photography itself was shaped by an experience of the silencing actively performed by both his family and the French authorities. ${ }^{44}$ The distortions which mark his earliest photographs from Algeria - and which are never resolved throughout his photographic practice - emphasise the significance of Boudjelal's repressed background for the negotiation of his photographic language. ${ }^{45}$ I thus read the blurred, estranged and distanced views of Algeria as symptomatic of the brutal repression and violent silencing which constituted, to use Butler's terminology, the 'frames' that marked Boudjelal's life in France, and especially his adolescent years in the I960s and 70s - a period which Stora defines as one of 'désirs d'oubli' ['a will to forget']. ${ }^{46}$

These 'frames' become metaphorised in Boudjelal's photographic language through the use of blur and mediating surfaces such as windows, architectural elements or textures, as is apparent in a photograph of two silhouettes tightly framed by the balusters of a balcony (c. I999, figure 7). The caption in Manière de voir informs us that the picture was taken in Sétif, the province where Boudjelal's family live and the destination of his first journey to Algeria in I993. Yet the figures remain unidentifiable, cast against a monotonous background of paved alleys which produces an alienating effect. The focal point of the image is constituted by the balusters, which form a physical obstruction to clear vision, rendering it instead definitely partial, similar to Boudjelal's photograph of the dancing figures who, occupying the foreground, frame the women sitting in the back of the room. It is from within the space of the family and its entangled histories that an unclear vision emerges. Yet these photographs do not only point to an occluded or obstructed vision; the balusters and the dancing figures assume a framing function, foregrounding a carefully constructed 'way of seeing'.

In the pages of Manière de voir, the photograph is inset in an article entitled 'I7 octobre I96I, la fin de l'oubli' [I 7 October I96I, The End of Forgetting], which queries memories of the violence enacted by French police against a peaceful demonstration of Algerians who supported the FLN, held in Paris in I96I.${ }^{47}$ The author of this article, Claude Liauzu, notes that half a century after the events unfolded, some of the archival documentation had still not been 


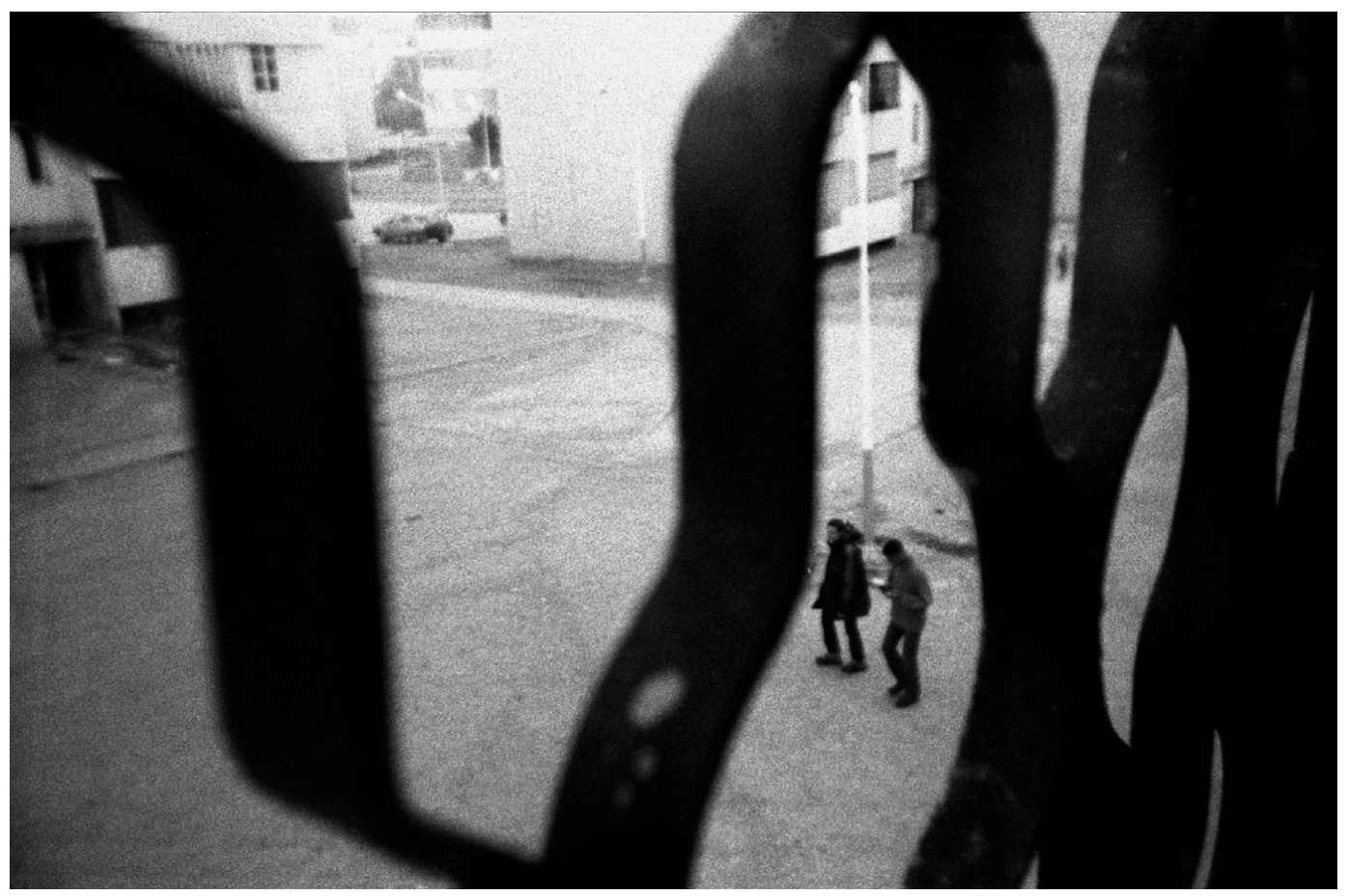

Figure 7 Bruno Boudjelal, Disquiet Days/Jours intranquilles, I999. Black \& white print / Hahnemühle Photo Rag Bright White 3 I $0 \mathrm{gr}, 30 \mathrm{~cm} \times 45 \mathrm{~cm}$. Reprinted in Claude Liauzu, 'I7 octobre I96I, la fin de l'oubli', Manière de voir-Le Monde diplomatique, no. I2 I, FebruaryMarch 20I2, pp. 82-84, p. 83. (C) Bruno Boudjelal and Agence VU.

made public - or had indeed disappeared from the files at the police prefecture - hindering any enquiry into the past. ${ }^{48}$ The historian Jean-Luc Einaudi's attempt to reconstruct the violence that was unleashed that day, in his book La Bataille de Paris: 17 octobre 1961 (I99I), was based entirely on testimonies of witnesses since police archives remained sealed until I999. As Joseph McGonagle has pointed out, the name of the association which recovered the debates about the events of I96I in the I990s in France was called Au nom de la mémoire [In the Name of Memory], identifying memory as locus of historical awareness when faced with a shortage of archival documents. ${ }^{49}$ Further, since President Charles de Gaulle passed amnesties in I968 which rendered it impossible to call any policeman involved in the violence to trial, it was only in 1999 that the French courts recognised Einaudi's right to apply the word 'massacre' when writing about the violence of 17 October I96I. ${ }^{50}$

The obstructed vision which Boudjelal's photograph foregrounds is mobilised within the magazine with the purpose of mapping two types of 
erasures: the gaps in the archives and the withholding of archival records from public view, which resulted in the silencing of the memory of one of the worst moments of state repression in French modern history. At the time of Manière de voir's publication, the violent repression of the demonstration had not yet been officially recognised by any French head of state; it would become acknowledged on the 5Ist anniversary of its unfolding, on I7 October 2OI 2. ${ }^{5 \mathrm{I}}$ The balusters that block vision and construct a partial view in Boudjelal's photograph uncover, symbolically, these acts of occlusion. These are further visualised in a photograph depicting a woman standing on a balcony taken from a window across the street. The view is partially obstructed by a half-lifted curtain, which occupies the left half of the photograph (early 2000s, figure 8). Screens structure the image, as the dark, heavy curtain in the foreground is echoed by the white, diaphanous curtain on the balcony opposite, doubled by its black shadow. Animated by this interplay between materials, the image appears unstable, as if threatened by the possibility of the curtain falling down, ending our voyeuristic experience. Throughout the iconographical programme of Manière de voir, through fragmentation,

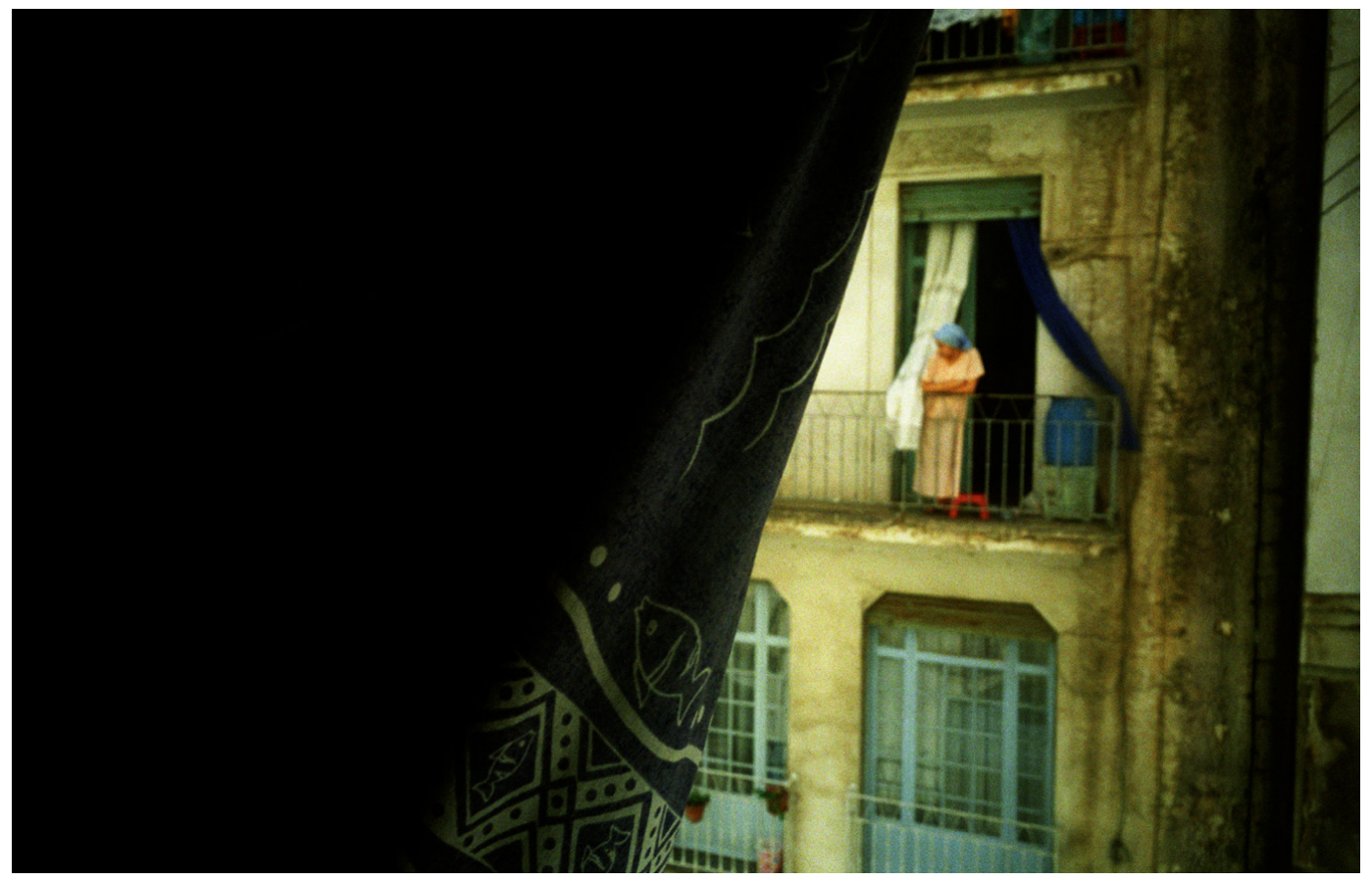

Figure 8 Bruno Boudjelal, Central Algiers, early 2ooos. Colour print / Hahnemühle Photo Rag Bright White 3 Io gr, $40 \mathrm{~cm} \times 60 \mathrm{~cm}$. (C) Bruno Boudjelal and Agence VU. 
blur and the use of mediating surfaces, the very processes, both psychic and political, that structure vision are subjected to constant pressure.

Manière de voir too acts as a 'frame' that structures vision as it confronts readers with a carefully devised iconographical programme that forms a lens through which to revisit a contested past. In fact, both the bimonthly magazine and Le Monde diplomatique share a stated commitment to move beyond 'the common illustrative function of the image'. ${ }^{2}$ Indeed, the editorial published in the first issue of Manière de voir in I987 identified the need to establish a new way of seeing that would counteract the partial vision caused by an accelerated circulation of images in the late twentieth century. ${ }^{53}$ Seeking to endorse attentive viewing, each issue of the magazine features images authored by either a single artist or photographer, or by a small number of practitioners. In the $20 \mathrm{I} 2$ issue devoted to Algeria's modern history, an extended and perhaps more responsible viewing is encouraged through the inclusion of Boudjelal's fragmented and blurred photographs.

While Nora considered realms of memory - which did not include the Algerian decolonial struggle - as fixed sites that unite collective memory, Rothberg has suggested, after James Young, that 'sites of memory do not remember by themselves - they require an active agency of individuals and publics'. ${ }^{54}$ Historically, it was the political Left in France that raised alarm against the use of torture in Algeria, with Sartre, Alleg and Simone de Beauvoir advocating an end to the violence they witnessed. ${ }^{55}$ Manière de voir aligns itself with these traditions. Even in 2000, it was the French Communist Party that put pressure on Chirac and Jospin to raise the question of official repentance vis-à-vis the French presence in Algeria - and the use of torture - in the French parliament. ${ }^{56}$ While their request was rejected, it revealed the persisting struggles of the French political sphere to critically assess the 'frames' that occluded certain memories of the war.

In the pages of Manière de voir, Boudjelal becomes an agent who interrogates these 'frames' imposed on his own relationship with Algeria. While the cover of Manière de voir promises an inquiry into the history of Algeria of the second half of the twentieth century and early twenty-first century, it remains preoccupied with questions of memory, as suggested by the title of the magazine's final section. History and memory become closely entangled rather than split into binary categories. By weaving these two categories together, the magazine elicits a consideration that the writing of 
history also necessitates an inquiry into the restrictions placed upon memory - spanning family repression and state-imposed amnesties and censorship that determine the types of histories we write.

\section{Conclusion}

Examining the limitations of images of war, Butler has argued that

to learn to see the frame that blinds us to what we see is no easy matter. And if there is a critical role for visual culture during times of war it is precisely to thematise the forcible frame, the one that conducts the dehumanising norm. ${ }^{57}$

Police photography is an unlikely site for exposing the 'frame' which presented Hamid as criminal rather than victim. However, in inscribing the mugshot in the photographer's personal version of history, his mediated and refracted experience of it, Scrapbooks destabilises its role as document of Algerian submission to French colonial rule, a marker of 'otherness', both ethnic and juridical. Inhabiting Boudjelal's laboriously assembled family album and acquiring new layers of meaning, its initial resonance shifts, echoing Allan Sekula's assertion that the mugshot falls into a category of photographic portraiture, 'a system of representation capable of functioning both honorifically and repressively', and suggesting that images amass meanings external to those inscribed in them at the moment of their production. ${ }^{58}$

Building on these shifting contexts, the mugshot's reproduction in Manière de voir further dislocates its original meaning, drawing attention to the interplay between that which can be seen in the photograph and that which was occluded from the camera and the public in France during the war and in its aftermath. While the excessive voyeurism embedded in the act of torture and described by Alleg never enters the image, the fading portrait of a man lost to war encourages readers to look outside of the frame and acknowledge the realities out of which photographs emerge. It is through Boudjelal's contemporary images, which consistently negotiate the processes conditioning a fragmented and blurred vision, that we begin to look for what is not readily visible in the archival photograph: the torture and death of the subject. While Butler argued that, in times of war, photography 'can only be conducted within certain kinds of lines and so within certain kinds of frames', she also suggested that there might be a way of making 'the mandatory 
framing' part of the visual narrative and 'to photograph the frame itself. ${ }^{59}$ Reprinted in Manière de voir, Boudjelal's photographs obstruct, page by page, readers' access to what is represented. It is impossible to 'see clearly', as Sartre advocated. The violence of silencing and repression, which is belatedly traced and challenged in Boudjelal's photographs, is thematised in the issue to address the erasure of torture from public discourse and its contested position between the fields of visibility and invisibility. Notably, it would only be ten months after this issue of Manière de voir was published - in December 2012 - that the newly elected President François Hollande condemned the use of torture by the French army during the Algerian War of Independence. ${ }^{60}$

Archives occlude as much as they reveal, and thus must be understood as sites of ethical and political inquiry, and pressure. While Stora suggested a correlation between the impasse of visual representations and the blind spots in the French collective imagination of the war, Manière de voir foregrounds the mechanisms that determine how a conflict's visibility is structured, both during war and in its aftermath. As Hamid's mugshot becomes mobilised within the contested context of torture, the need for a constant investigation into the 'frames' that shape not only the production of images during war but also the archival afterlives of these images - which enact violent erasures upon them - comes to the fore. Following a long delay in making photographic archives of the Algerian War of Independence available to the public, what is needed is an investigation into the cultural, social and political processes which control and structure vision itself, in order to be able to see beyond the 'frame' and understand how it constitutes subjectivities. The FebruaryMarch 2012 issue of Manière de voir provides one take on such a project.

\section{Notes}

I am grateful to my supervisors, Tamar Garb and Azzedine Haddour, for their advice on this article. I would like to thank Bruno Boudjelal and Agence VU for providing image permissions, Benjamin Doizelet for his help during archival research at the Service historique de la Défense in Paris and Mallika Leuzinger for her insights. Funding for this project was generously provided by the London Arts and Humanities Partnership.

I The three sections of the magazine are titled 'Rêves, espoirs et mirages' ['Dreams, Hopes and Mirages'], 'Douloureux réveil' ['Painful Awakening'] and 'Le Poids de la mémoire' 
['The Weight of Memory'], in Manière de voir-Le Monde diplomatique, no. I2 I, FebruaryMarch 20I2. All translations from French are the author's, unless stated otherwise.

2 See Marie Chominot, 'Guerre des images, guerre sans image. Pratiques et usages de la photographie pendant la guerre d'indépendance algérienne (1954-1962)', in Insaniyat/ إنسانيات, no. 39/40, 2008, pp. I75-I95.

3 Laurent Gervereau, 'Cécité, absences inévitables et part maudite', in Laurent Gervereau and Benjamin Stora (eds), Photographier la guerre d'Algérie, Paris, 2004, pp. 75-78, p. 75.

4 See Todd Shepard, "Making Sovereignty and Affirming Modernity in the Archives of Decolonisation. The Algeria-France "Dispute" between the Post-Decolonisation French and Algerian Republics, I962-20I5', in James Lowry (ed.), Displaced Archives, New York, NY and Abingdon, 2017, pp. $2 \mathrm{I}-40$.

5 In February 20I2, when Manière de voir was published, military documents up to the year I96I were available. Documents from 1962 became available on I January 2013. Service historique de la Défense/Centre historique des Archives/Département des fonds d'archives, Paris, email communication, I6 March 2017.

6 Analysing filmic representations of the war after its end, Stora identified $3 \mathrm{I}$ feature films produced in France between 1962-82. However, these addressed selected memory groups and did not offer a broader understanding of the conflict. Benjamin Stora, $\mathrm{La}$ gangrène et l'oubli: La mémoire de la guerre d'Algérie, Paris, I99I, pp. 248-249. Indeed, the period of I954-62 was not recognised as 'war' by France until I999, demonstrating the lack of a national consensus. See Martin Evans, Algeria: France's Undeclared War, Oxford, 2002.

7 Stora, op. cit., p. 248.

8 Ibid., pp. $248-256$. For a discussion of the shifting role of visual culture during the wars in Algeria and in Vietnam, see Benjamin Stora, Imaginaires de guerre. Les images dans les guerres d'Algérie et du Viêt-Nam, Paris, 2004.

9 See Michèle Bacholle-Bošković, 'Quelles commémorations pour les cinquante ans de la guerre d'Algérie?', in French Cultural Studies, vol. 25, no. 2, 20I4, pp. 233-245; and Benjamin Stora and Mohammed Harbi, La Guerre d'Algérie: 1954-2004, la fin de l'amnésie, Paris, 2004.

Io Benjamin Stora, La Guerre des mémoires: la France face à son passé colonial. Entretiens avec Thierry Leclère, Paris, 2007, p. 84. In 20I2, the relationship between Algeria and France remained strained. Algeria refused to host French officials during the celebrations of the 5oth anniversary of independence. The deterioration in the relations between the two countries occurred after a short-lived law was introduced on 23 February 2005 , which required teachers in France to recognise the positive effects of French colonialism, particularly in North Africa. It was repealed in 2006.

I I Jonathan Mathew Finn, Capturing the Criminal Image: From Mug Shot to Surveillance Society, London and Minneapolis, MN, 2009, p. 2.

I2 Nicolas Bancel, Pascal Blanchard and Sandrine Lemaire, 'La Torture en miroir', in Manière de voir, op. cit., pp. 80-82, p. 8I.

I 3 Bruno Boudjelal, Disquiet Days/Jours intranquilles, (ed. and trans.) Tom O’Mara, London, 2009.

I4 For a discussion of the problems faced by Algerian immigrants to France during and after the war, see Marie-Claude Blanc-Chaléard, 'Old and New Migrants in France: 
Italians and Algerians', in Leo Lucassen, David Feldman and Jochen Oltmer (eds), Paths of Integration: Migrants in Western Europe 1880-2004, (trans.) Christopher Mobley, Amsterdam, 2006, pp. 46-62.

I5 Boudjelal, op. cit., diary entry 20 July I997, n.p.

I6 Bruno Boudjelal, Paris, personal interview, December 2016.

I7 Bancel, Blanchard and Lemaire, op. cit., p. 82.

I 8 Judith Butler, Frames of War: When is Life Grievable, London and New York, NY, 2010, pp. $72-73$.

I9 Ibid., p. 73 .

20 For example, French authorities thoroughly documented the massacre of 28 May I957 when the Armée de liberation nationale (National Liberation Army), or ALN - the armed wing of the Front de libération nationale (National Liberation Front), or FLN - killed 374 villagers in Mélouza, suspected of sympathising with the Mouvement national algérien (Algerian National Movement), or MNA, an organisation founded by Messali Hadji in opposition to the FLN. Benjamin Stora, 'France: images vues, perdues, retrouvées', in Stora and Gervereau, op. cit., pp. 93-II 8, p. 95.

2 I Henri Alleg, La Question, Paris, 2008, p. I9.

22 See James D. Le Sueur, 'Torture and the Decolonisation of French Algeria: Nationalism, "Race" and Violence in Colonial Incarceration', in Graeme Harper (ed.), Captive and Free: Colonial and Post-Colonial Incarceration, London, 2002.

23 Florence Beaugé, 'Torturée par l'armée française en Algérie, "Lila" recherche l'homme qui l'a sauvée', Le Monde, 20 June 2000, pp. I and Io.

24 F. Beaugé, 'Comment Le Monde a relancé le débat sur la torture en Algérie', Le Monde (I7 March 20I2), http://www.lemonde.fr/afrique/article/2012/03/I7/le-monderelance-le-debat-sur-la-torture-en-algerie_I669340_32 I 2.html (accessed 4 September 20I7).

25 See 'Torture en Algérie: le remords du général Jacques Massu', Le Monde, 22 June 2000, p. I; F. Beaugé, 'Le Général Massu exprime ses regrets pour la torture en Algérie' and ' $\mathrm{La}$ torture faisait partie d'une certaine ambiance. On aurait pu faire les choses différemment', Le Monde, 22 June 2000, p. 6; 'Les Remords d'un général', editorial, Le Monde, 22 June 2000, p. I6.

26 'Déclaration de M. Lionel Jospin, Premier ministre, en réponse à une question sur le débat sur la torture pendant la guerre d'Algérie, à l'Assemblée nationale le 28 novembre 2000', Vie Publique (30 November 2000), http://discours.vie-publique.fr/ notices/0030033I9.html (accessed 4 September 20I7).

27 B. Stora, Le Livre, mémoire de l'histoire: réflexions sur le livre et la guerre d'Algérie, Paris, 2005 , p. $2 \mathrm{I}$.

28 Alleg, op. cit., pp. 22.

29 Stora and Gervereau, 'La Guerre inégalitaire', in Stora and Gervereau, op. cit., pp. 7-9, p. 8 .

30 The few photographs that exist are held in private collections and at the Bibliothèque nationale de France where they are subject to strict institutional regulations. The Service historique de la Défense, the Agence d'Images de la Défense and the Archives nationales d'outre-mer do not hold any photographs depicting acts of torture enacted on Algerians. 
3 I See Christophe Bertrand (ed.), Algérie 1830-1962 avec Jacques Ferrandez, exh. cat., Paris, 2012 , p. I 52.

32 'Le Journal de bord d'un haut fonctionnaire en Algérie', Réalités, no. I32, January i957; Christine Vaissié-Charbonnier, Paris, email communication, I3 March 20 I 7.

33 Bibliothèque nationale de France, Paris, email communication, 29 September 2016.

34 Ibid.

35 It was not possible to consult or reproduce the original photographs for the purposes of this article.

36 Laurent Gervereau and Benjamin Stora, 'La Guerre inégalitaire', in Gervereau and Stora op. cit., pp. 7-9, p. 8. While the authors acknowledge in the introduction to the publication that the war was only selectively represented and these occlusions require further investigation, they relocate torture further into pictorial invisibility by not discussing any examples or the restrictions prohibiting the emergence of such visualisations. While photographs of torture may be rare, there exist images that thematise this violence without explicitly showing it. For example, Marc Garanger's photograph from April I96I, which depicts a man locked in a prison that also served as torture chamber (reprinted in Marc Garanger, La Guerre d'Algérie: vue par un appelé $d u$ contingent, Paris, I984) could have served as an example of wartime photographic responses to torture.

37 Anne Mathieu, 'Jean-Paul Sartre et la guerre d'Algérie', in Manière de voir, op. cit., pp. 88-9i.

38 Jean-Paul Sartre, 'You Are Wonderful' (I957), in Colonialism and Neocolonialism, (trans.) Azzedine Haddour, London and New York, NY, 200I, pp. 63-7I, p. 64.

39 Perry Anderson, The New Old World, London, 20 I i, p. I6I.

40 Michael Rothberg, 'Between Memory and Memory: From Lieux de mémoire to Noeuds de mémoire', in Yale French Studies, no. i I8/I I9, 2010, pp. 3-12, p. 6.

4I The family was the sole safe environment during the civil war, suggesting that Boudjelal might have developed an alternative visual language on this basis. For a discussion of the restrictions in photographing the civil war, see Joseph McGonagle, 'Dispelling the Myth of Invisibility: Photography and the Algerian Civil War', in Liam Kennedy and Caitlin Patrick (eds), The Violence of the Image. Photography and International Conflict, New York, NY, and London, 2014, pp. 78-96.

42 Amanda Crawley Jackson, 'RETOUR/DÉTOUR: Bruno Boudjelal's Jours intranquilles', in Nottingham French Studies, vol. 53, no. 2, 20I4, pp. 20I-2 I5, p. 203.

43 Boudjelal, op. cit., diary entry i6 April 2002, n.p.

44 For a discussion of memory transmission among Algerian immigrants in France, see Alec G. Hargreaves, 'Generating Migrant Memories', in Patricia Lorcin (ed.), France E Algeria: Identity, Memory and Nostalgia, Syracuse, NY, 2006, pp. 2 I 7-227.

45 While Boudjelal travelled to Algeria in 1993 to meet his family, he first took what he calls a 'detour' and travelled through the country for a week. The opening photographs of Disquiet Days/Jours intranquilles, following Scrapbooks, are thus blurred, grainy blackand-white photographs of empty roads and street scenes, often taken through mediating surfaces such as hotel windows. Boudjelal, Paris, personal interview, 20 I6.

46 Stora, op. cit., I991, pp. I90-275.

47 For a discussion of these events, see Jean-Luc Einaudi, La Bataille de Paris: 17 octobre 
1961, Paris, 200I; and Jim House and Neil MacMaster, Paris 1961: Algerians, state terror, and memory, Oxford, 2009.

48 Claude Liauzu, 'I7 octobre I96I, la fin de l'oubli', Manière de voir, op. cit., pp. 82-84, p. 83 .

49 Joseph McGonagle and Edward Welch, Contesting Views: The Visual Economy of France and Algeria, Oxford, 2013 , p. 66.

50 Joshua Cole, 'The Memory of Police Violence in Paris, October I96I', in Lorcin, op. cit., p. I20.

$5 \mathrm{I}$ 'Hollande reconnaît la répression du $\mathrm{I} 7$ octobre I96I, critiques à droite', Le Monde (I7 October 20I2), http://www.lemonde.fr/societe/article/20I2/IO/I 7/francoishollande-reconnait-la-sanglante-repression-du-I7-octobre-I96I_I 7769I 8_3224.html (accessed 4 September 20I7).

52 'Qui sommes-nous?', Le Monde diplomatique, http://www.monde-diplomatique.fr/ diplo/apropos/ (accessed 4 September 2017).

53 Claude Julien, editorial, in Manière de voir-Le Monde diplomatique, no. I, November I987, http://www.monde-diplomatique.fr/mav/or/JULIEN/50922 (accessed 4 September 2017).

54 Rothberg, op. cit., p. 8.

55 On 2 June 1960, Simone de Beauvoir published an article in Le Monde recounting the violence experienced by Djamila Boupacha, a young FLN fighter who was raped and tortured by French soldiers. See Simone de Beauvoir, 'Pour Djamila Boupacha', Le Monde (2 June 1960), http://www.lemonde.fr/archives/article/I960/o6/o2/pourdjamila-boupacha_2092987_I8I92 I 8.html (accessed 4 September 2017); and Simone de Beauvoir and Gisèle Halimi, Djamila Boupacha, Paris, 1962.

56 Gilles Bresson and Didier Hassoux, 'Torture en Algérie: Jospin refuse la voie parlementaire', La Libération (24 November 2000), http://www.liberation.fr/ france/2000/I I /24/torture-en-algerie-jospin-refuse-la-voie-parlementaire_345346 (accessed 4 September 2017).

57 Butler, op. cit., p. Iоo.

58 Allan Sekula, 'The Body and the Archive', in October, no. 39, I986, pp. 3-64, p. 6.

59 Butler, op. cit., p. 7I.

60 'Hollande dénonce la colonisation "brutale" en Algérie', Le Monde Afrique (20 December 20I2), http://www.lemonde.fr/afrique/article/20I2/I2/20/hollandedenonce-la-colonisation-brutale-en-algerie_I8089I I_32 I2.html (accessed 4 September 20I7). 